\title{
The Implementation of Character Education at Senior High School
}

\author{
Julia $^{*}$ and Tedi Supriyadi \\ Program Studi PGSD, Universitas Pendidikan Indonesia Kampus Sumedang, Jl. Mayor Abdurachman \\ No. 211 Sumedang, Jawa Barat, Indonesia
}

\begin{abstract}
This paper is aimed at analyzing the implementation of character education at Senior High School in Sumedang Regency, West Java, Indonesia. A content analysis method was employed to collect the data with interviews with six teachers from six different senior high schools, which represent the rural, transitional, and urban areas. The findings revealed that: (1) not all teachers understand the concept of character education; (2) the character education has not been done systematically or has not had the specific design/model for the teaching and learning process. Most teachers embedded the character values during the teaching and learning process as a form of character education. For example, through Qur'an recitation, learning tasks, group discussion, lecture, sociodrama, observation and admonition, and even through teachers' model. Meanwhile, outside the class, character education was implemented through competition and extracurricular activities; (3) the evaluation of character education was relatively varied, such as an observation followed by admonition, group guidance, and also focusing on behavior and affective assessment in the classroom learning process. This research implied that it is needed to make a policy on a program development through the Bureau of Education to improve Senior High School teachers' knowledge and skills in implementing the character education. Keywords: character education, senior high school, implementation, evaluation.
\end{abstract}

\section{Introduction}

Character education is now one of the main topics in the implementation of education in Indonesia. Since its inception in January 2010, which was reinforced by the president's speech in the commemoration of the National Education Day on May 2, 2010 [1] , character education continues to be developed through various education programs both within the Ministry of Education and Culture, such as research grants from Center for Education Policy Research (Puslitjakdikbud), as well as within the Ministry of Research, Technology and Higher Education (Kemenristekdikti).

On the local government level, such as Sumedang Regency in West Java in 2013 released a Regent Regulation that provides guidelines to the Sundanese people to behave within the norms of the kasundaan (Sundanese) culture and character [2, $\underline{3}]$. The Sundanese character consists of 10 main characters that include taqwa (pious/religious), someah

\footnotetext{
* Corresponding author: juli@upi.edu
} 
(friendly), surti (empathetic), jembar (broadminded), brukbrak (transparent), guyub (getting along with others), motekar (creative), tarapti-taliti-ati-ati (meticulous, careful), jununjucung (work well, consistent), and punjul-luhung (high competence) [2]. The ten characters, in addition to having distinctive differences, also have similarities to the 10 pillars of character education set by Lickona, namely trustworthiness, respect, responsibility, fairness, caring, honesty, courage, diligence, integrity, and citizenship [ $\underline{4}, \underline{5}]$. The creation of various programs or regulations on character education, one of them is triggered by the behavior of the Indonesian people, particularly school students, which increasingly show behaviors of anticulture and anticharacter of the nation which have been reported by various mass media [6-9]. However, a person's characters are essentially influenced by the intercommunication within the surrounding community. Psychologists show that as part of socialization, people internalize the norms and values of their society [10-12].

Since the national culture and character education have been implemented for approximately seven years, it is necessary to see the application in the field, specifically in schools. In general, based on the results of preliminary studies, teachers in schools do not have a design in applying character education, especially high school teachers in Sumedang Regency. According to Suryadi [13], character education is a value education program that is packed not in the form of subjects, but in the embodiment of the school as a character institution. Therefore, this study attempts to analyze three aspects, namely: (1) how is the teacher's understanding of character education?; and (2) what is the form of character education implementation?

\section{Methods}

This study employed a content analysis method. The data were taken by interviews with six teachers from six high schools in Sumedang Regency, West Java, Indonesia, in the 2015/2016 school year. The selected schools represent two schools from the urban area, two schools from the transition area, and two schools from the rural area. The first respondent (R1) was academically qualified as a civics education teacher, the second respondent (R2) was an Islamic religion teacher, the third respondent (R3) was a Mathematics teacher, the fourth respondent (R4) was a Physics teacher, the fifth (R5) was an Indonesian language teacher, and the sixth respondent (R6) was a Guidance and Counseling teacher. The data analysis was conducted based on Miles and Huberman [14] flow model, as translated by Rohidi [15], which consists of data collection, data reduction, data display, and conclusion.

\section{Results and Discussions}

\subsection{Understanding of Character Education}

The presented findings are translated results of the interviews with the six respondents.

Interviewer

$\mathrm{R} 1$ responded

$\mathrm{R} 2$ responded

$\mathrm{R} 3$ responded

$\mathrm{R} 4$ responded

$\mathrm{R} 5$ responded
: How is your understanding of character education?

: "(I) have read and tried to understand the culture and character education program."

: "(I) have understood the cultural education and character program in KTSP (school-based curriculum)."

: "(I) have only understood the cultural education and character program a little."

: "(I) have only understood a part of the cultural education and character program."

: "(I) have understood the cultural education and character program, because at school where I teach, there was a teacher that had been 
trained in culture and character education and it had been socialized."

R6 responded : "(I) have understood the cultural education and character program."

Based on the aforementioned data, it can be identified that the understanding of character education among teachers at the senior high school level was varied. From the example, three teachers had understood culture and character education, two teachers had not fully understood the culture and character education program, and one teacher had just tried to understand the culture and character education program. Of the six respondents, only one respondent mentioned the training on culture and character education, thus the information about culture and character education from the training was obtained which was then disseminated to the teachers. In order to provide better learning, the teachers should improve their understanding and skill as it has done by the teachers in Russia. Hauer [16] stated that Russian teachers worked with a trainer to improve their understanding and skills in character and moral education. Dengan demikian, guru bisa memberikan perlakuan yang berbeda terhadap peserta didik, bahkan guru bisa memiliki karakter sebagai a caring teacher as a navigator, gardener, leader, or servant [17].

\subsection{Implementation of Character Education}

The following are translated results of interviews with the six respondents.

Interviewer : What is the learning model used in applying character education?

$\mathrm{R} 1$ responded : "As a Civics teacher, culture and character education is already integrated in the learning of civics education, and it is taught to learners starting from their arrival at school, in the classroom, outside the classroom, and outside the school. In the model of culture and character education that I apply, there must be mutual respect for people who are speaking, asking a question, and listening, and there is even a lesson about discussion procedure, how the procedure of good discussion, I think... at least as a Civics teacher, I have standards about the procedure of deliberation in general and in the Sundanese way."

$\mathrm{R} 2$ responded : "As a teacher of religion (Islam), then religious education is automatically very relevant to culture and character education, because the goal of religious education is to foster the children to have noble characters. The implementation model of culture and character education (that I use), in addition to being fed with various sciences, may be with examples of the performance of a teacher as an educator and how a teacher must behave in front of the children so that the child can see and, 'Oh, this one must be followed."'

$\mathrm{R} 3$ responded : "If any students committed violations, they would be immediately reminded or called to the Guidance and Counseling room or to the teacher's office to receive counseling as a form of character education. Sometimes, in the classroom, things that are related to it (character education) were included. For example, if there was a child breaking a rule, we would talk in front of the classroom for a minute or two for everyone."

R4 responded : "During classroom learning, some aspects of culture and character education have been implemented, such as instilling honesty, discipline, whether in submitting tasks or in doing exercises. There 
R5 responded : "The results of the teacher training on culture and character education are socialized and implemented in an integrated manner in every subject, including Indonesian language; for example, every student is required to memorize 10 verses of the Qur'an on the first hour of the day. In learning Indonesian language, there is a lesson to criticize sentences... I think it is already there... the philosophy of Sundanese language in every attitude and behavior of students either during the learning or outside the learning."

R6 responded : "Cultural education and character are included in Guidance and Counseling material, such as the values of life, which connect the daily life of the students with society life... as well as about ethics and norms, either written or unwritten which are usually discussed in the classroom or in group guidance. For the learning model, once there were examples (presented in) a socio-drama about life values... such as saving ten magical people from a sinking ship."

There are various opinions regarding the implementation of character education [18-34]. In other words, in applying character education, there are various references that can be implemented, such as referring to Kohlberg [34] who divides students' character development in three stages: pre-conventional reasoning, conventional reasoning, and postconventional reasoning, or referring to Lockheed and Verspoor [35] who formulate the concept that character education is performed through four stages; the initial stage, the formal stage, the transitional stage, and the stage of meaning. Otherwise, referring to Hendarman, Saryono [36] who state how to strengthen character education on the basis of classroom, school culture, and society.

The above data shows that the implementation of character education programmed in national level have not had a special form or design in the learning process yet. As from the case examples, four teachers believed that culture and character education was relevant or integrated with the subjects they taught, one teacher implemented it through learning tasks, and one teacher implemented it by giving reprimands or direct behavioral guidance. The implementation of Sundanese character education had been programmed by the local government by the obligation to use Sundanese language and traditional outfit. However, since it had not been integrated into the curriculum, the program did not run well, especially in the use of Sundanese language by learners. The other forms of implementation were quite diverse, such as teaching panta-panta (levels of politeness) in Sundanese language, organizing competitions related to Sundanese culture, integration with school vision and mission, and integration with $3 \mathrm{~S}$ programs. All of the teachers also expressed that they had not had specific models or designs for Sundanese character education, and they implemented character education as supplementary in the learning process, such as making the students to get used to read Al-Quran before the first lesson begins, and to get used to kiss the teachers' hand palm. The forms of the implementation of character education in the process of learning in the classroom were embodied in several forms, such as group discussion with the emphasis on the particular character, teacher exemplary, short lectures on the norms, observations and warnings about the learners' characters, and socio-drama about life values. Without employing the character education model, at least, the teachers should be the model of the character education as Abebe and Davis [37] point out that 
teachers are expected to be the moral model in school. Therefore, Waterson [38] notes that teachers teach students not only methodology and content, but also values.

\section{Conclusions}

The conclusion drawn from the results of this study is that high school teachers in Sumedang Regency did not show their understanding of the concepts of character education that have already existed globally. Therefore, both the form of implementation and evaluation tend to be in a form of guidance or daily activities that are usually delivered to the learners in the learning process at school, both routine and incidental.

The authors would like to thank the Bappeda of Sumedang Regency and Puslitjakdikbud who had facilitated this study, and to the Board of Education of Sumedang Regency who assisted in the study process.

\section{References}

1. Marzuki. Revitalisasi Pendidikan Agama di Sekolah dalam Pembangunan Karakter Bangsa di Masa Depan. Jurnal Pendidikan Karakter. 1:64-76 (2013).

2. Bappeda. Peraturan Bupati Sumedang Nomor 113 Tahun 2009 tentang Sumedang Puseur Budaya Sunda. Sumedang BK. (2009).

3. Fahdini R, Julia, Suhandani D. Implementasi Pendidikan Karakter Kasundaan Sebagai Upaya Membangun Budaya dan Karakter Bangsa (Survei Pada Anak SMA di Kabupaten Sumedang). Sumedang: Bappeda Kab. Sumedang. Tidak Dipublikasikan. (2015).

4. Lickona T. Educating for character: How our schools can teach respect and responsibility. New York: Bantam Books (2009).

5. Wahyu. Masalah dan Usaha Membangun Karakter Bangsa. In: Budimansyah D, Komalasari K, editors. Pendidikan Karakter: Nilai Inti Bagi Upaya Pembinaan Kepribadian Bangsa. Bandung: Widya Aksara Press (2011).

6. Kompasiana.com. Anak SD Melakukan Pembunuhan Berencana Terhadap Temannya. (2012). Accesed on: 20 October 2016. Available from: http://www.kompasiana.com/iraannisa/anak-sd-melakukan-pembunuhan-berencanaterhadap-temannya 552bb5b36ea8344f6f8b457b.

7. Sindonews.com. Masih di Bawah Umur, Terdakwa Kasus Penganiayaan Dibebaskan. (2016). Accesed on: 10 December 2016. Available from: https://metro.sindonews.com/read/1104013/170/masih-di-bawah-umur-terdakwakasus-penganiayaan-dibebaskan-1461596823.

8. Liputan6.com. Kedapatan Mencuri HP, Tiga Anak SD Diringkus. (2010). Accesed on: 13 Mei 2016. Available from: http://news.liputan6.com/read/292114/kedapatanmencuri-hp-tiga-anak-sd-diringkus.

9. Pikiran-rakyat.com. Masih Ada Pelajar SMP Pesta Miras Oplosan di Sumedang. (2014). Accesed on: 18 April 2015. Available from: http://www.pikiranrakyat.com/jawa-barat/2014/12/19/309139/masih-ada-pelajar-smp-pesta-mirasoplosan-di-sumedang.

10. Campbell EQ. The internalization of moral norms. Sociometry.391-412 (1964).

11. Henrich J, Boyd R, Bowles S, Camerer C, Fehr E, Gintis H, et al. In search of homo economicus: behavioral experiments in 15 small-scale societies. The American Economic Review. 91:73-8 (2001).

12. Mazar N, Amir O, Ariely D. The dishonesty of honest people: A theory of selfconcept maintenance. Journal of marketing research. 45:633-44 (2008).

13. Suryadi A. Pendidikan Karakter Bangsa: Pendekatan Jitu menuju Sukses Pembangunan Pendidikan Nasional. In: Budimansyah D, Kamalasari K, editors. 
Pendidikan Karakter: Nilai Inti Bagi Upaya Pembinaan Kepribadian Bangsa. Bandung: Widya Aksara Press (2011).

14. Miles MB, Huberman AM. Qualitative data analysis: An expanded sourcebook: sage (1994).

15. Rohidi TR. Analisis Data Kualitatif. Jakarta: Universitas Indonesia (2007).

16. Hauer J. The Impact of Character Education on Russian Teachers: An Informal Survey, Spotlight on Josephine Hauer. Journal of College and Character. 1:null-null (2000).

17. Waterson R. The Art of Teaching: Ernest Shackleton as Navigator/Teacher. Journal of College and Character. 12:null-null (2011).

18. Allers R. Character education in adolescence. New York: Wagner (1940). 188 p. p.

19. Lickona T. Eleven principles of effective character education. Journal of moral Education. 25:93-100 (1996).

20. Bronfenbrenner U. Soviet methods of character education: Some implications for research. Religious Education. 57:45-61 (1962).

21. Johnston $\mathrm{CH}$. National Institution For Moral Instruction. The Journal of Education. 77:243- (1913).

22. Dreikurs R. Character education and spiritual values in an anxious age. Boston: Beacon Press (1952). 23 p. p.

23. Kuntz LF. Religion and Character Education. Religious Education. 49:255-63 (1954).

24. Yulish SM. The search for a civic religion : a history of the character education movement in America, 1890-1935. Washington, D.C.: University Press of America (1980). xii, 306 p. p.

25. Neall BS. The concept of character in the Apocalypse, with implications for character education. Washington, D.C.: University Press of America (1983). xii, 224 p. p.

26. Chinawa PO. The teacher's role in character education of the youth following the mind of Rudolf Allers. Rome: s.n. (1984). 135 p. p.

27. Gill (Aberystwyth) C. Plato and the Education of Character. Archiv fur Geschichte der Philosophie. 67:1-26 (1985).

28. Beswick R. Character Education. OSSC Bulletin. 35 (1992).

29. Kelsey IB. Universal character education. Edinburgh: Pentland Press (1993). xvi, 100 p. p.

30. Brooks BD, Goble FG. The case for character education : the role of the school in teaching values and virtue. Northridge, CA: Studio 4 Productions (1997). 161 p. p.

31. Lockwood AT. Character education: controversy and consensus. Thousand Oaks, California: Corwin Press (1997). viii, 71 p. p.

32. Mulkey YJ. The history of character education. Journal of Physical Education, Recreation \& Dance. 68:35-7 (1997).

33. Lickona T. The return of character education. Educational leadership. 51:6-11 (1993).

34. Kohlberg L. Revisions in the theory and practice of moral development. New directions for child and adolescent development. 1978:83-7 (1978).

35. Lockheed ME, Verspoor AM. Improving primary education in developing countries. Washington, D.C: Published for the World Bank, Oxford University Press (1991).

36. Hendarman, Saryono D, Supriyono, Kamdi W, Kartadinata S, Latipun, et al. Konsep dan Pedoman Penguatan Pendidikan Karakter. Jakarta: Pusat Analisis dan Sinkronisasi Kebijakan (2017).

37. Abebe S, Davis W. Transcendence in the Public Schools: The Teacher as Moral Model. Journal of College and Character. 5:null-null (2004).

38. Waterson RA. What is the Role of the Teacher? To Guide the Studies of Others. Journal of College and Character. 10:null-null (2009). 